\title{
Individual, Organizational and Institutional Determinants of Formal and Informal Inter-firm Cooperation in SMEs
}

Please, quote the final version of this paper published in the Journal of Small Business Management, https://doi.org/10.1111/jsbm.12445.

Abstract: Inter-firm cooperation has been considered an important strategy for SMEs to overcome competitive difficulties. Despite the relevance of this strategy there are no studies that jointly consider how entrepreneurs' characteristics, organizational factors and institutional features influence SMEs to establish cooperative agreements. In order to bridge this gap, we analyze what factors at these three levels explain inter-firm cooperation and whether formal and informal inter-firm agreements are explained by different factors. Our research is based on a survey of 1,587 Spanish SMEs and the results show that individual, organizational and institutional factors contribute to jointly shape the decisions concerning inter-firm cooperation.

\section{Introduction}

Inter-firm cooperation has been extensively discussed in the literature as a way to achieve results that individual firms could not achieve separately. Small and medium-sized enterprises (SMEs) cooperate to overcome the liability of smallness (Aldrich, and Auster 1986), access strategic resources (Pyke 1992; Narula 2004), enhance marketing strategies (O’Donnell 2014) and innovativeness (Okamuro 2007; Gronum, Verreynne, and Kastelle 2012). Such firms develop formal and informal agreements with customers, suppliers, research and development centers, and even competitors to overcome competitive problems (Kim, and Vonortas 2014). The organizational literature is fruitful in studies that show a 
positive relationship between cooperative agreements and organizational outcomes (Azadegan et al 2008; Powell, Koput, and Smith-Doerr 1996; Baum, Calabrese, and Silverman 2000). Some studies propose that cooperation may even be critical for the survival and prosperity of SMEs (Havnes, and Senneseth 2001; Schoonjans, Van Cauwenberge, and Bauwhede 2013).

Despite the importance of cooperation for SMEs, the explanation about why some firms establish more collaborative relationships than others remains incomplete. Previous studies have separately addressed how entrepreneur's characteristics (Guzmán, and Santos 2001), organizational factors (Brass et al. 2004) and institutional features (Oxley 1999; Sigmund, Semrau, and Wegner, 2015) influence business cooperation, but a limited number of studies jointly consider how factors in these three levels explain inter-firm cooperation in SMEs (i.e. Kim, and Vonortas 2014). The literature is also silent about how these factors differently explain the development of formal and informal cooperation agreements. Such a comprehension becomes important as informal inter-firm cooperation may be common in SMEs. Formal cooperation is based on contracts that determine the rights and obligations of the partners (Ring, and Van de Ven 1994; Smith et al. 1995). On the other hand, informal cooperation is based on informal and behavioral norms, rather then formal contracts (Ring, and Van de Ven 1994; Smith et al. 1995; Hadjielias, and Poutziouris 2015).

Based on the previous arguments, we set out the following research questions: What characteristics of the entrepreneur, the organization and the institutional environment explain the formation of inter-firm cooperation in SMEs? Are formal and informal inter-firm agreements explained by different factors? We consider inter-firm cooperation as any formal or informal agreement made by a firm with other companies (competitors, suppliers, clients or other partners), characterized by a relationship that goes beyond a market transaction. In order to answer these questions we differentiate SMEs that do not cooperate, those that exclusively mantain informal agreements, those that exclusively have formal agreements and those that 
develop both types of cooperation agreements. Our empirical research is based on a survey of 1,553 Spanish SMEs (<250 employees).

The results confirm that the individual, organizational and institutional factors contribute to jointly shape the decisions of SMEs on inter-firm cooperation. Among the individual factors, we observed the influence of entrepreneurial motivations, the entrepreneurs' education and social capital. Among the organizational factors, risk taking propensity, innovation, and the participation in Global Value Chains (GVC) are also found to determine the cooperation activity. Finally, regarding the institutional level, the paper shows how the obstacles perceived in the business environment can lead SMEs to cooperate with other companies. In this respect, we particularly show that the difficulties to access funding and qualified human resources stimulate inter-firm cooperation in SMEs. Furthermore, according to our results, high tax burdens might inhibit cooperation. Entrepreneurs can benefit from the results of this study to make their firms more inclined to cooperation and, consequently, have greater opportunities to improve performance. Policymakers can also use the results to encourage SMEs to establish cooperative agreements. The study contributes as well to organizational theory as it analyzes how variables at different levels affect the cooperation of SMEs.

\section{Literature Review}

Interorganizational cooperation has been analyzed from various theoretical perspectives that consider individual level factors (Gulati, and Gargiulo 1999; Zaheer, Gulati, and Nohria 2000), organizational level factors (Williamson 1975; Pahrke 1993; Dyer, and Singh 1998; Pfeffer, and Salancik 2003), and the context and the institutional environment (North 1990; Osborn, and Hagedoorn 1997; Deligonul et al 2013). In the case of SMEs, individual and organizational characteristics are significantly intertwined. An individual's 
profile may directly influence their organizational strategy (Kim, and Vonortas 2014) and their willingness to cooperate. Organizational characteristics may also influence the adoption of cooperative strategies. Besides that, institutional barriers limit organizational opportunities and may stimulate collaboration. In this sense, our analysis is divided into these three levels individual, organizational and institutional - to understand what factors explain the establishment of cooperation agreements in SMEs. The following subsections outline the literature review and the hypotheses that guide our research.

\subsection{Individual-level Factors}

Several characteristics at the individual level may explain the establishment of cooperative agreements in SMEs, such as the entrepreneur's educational level, the motivation to establish a business and the individual's social capital.

The entrepreneur's level of formal education and business training are mentioned in the literature as positively related to the creation of new firms (Delmar, and Davidsson 2000; Liñán et al. 2011) and the success of companies (Robinson, and Sexton 1994; Kangasharju, and Pekkala 2002). Higher levels of education and training broaden the entrepreneur's general knowledge about business management and legal issues such as contracts and business agreements. Therefore, it is expected that education and training expand his/her comprehension on how to establish and manage cooperation agreements, while minimizing the risks. Kim and Novorta $(2014$, p. 798$)$ argue that there is an "expectation that more educated entrepreneurs will lead more innovative companies and, all being equal, companies with higher opportunities to engage in formal networks". As a result, entrepreneurs with higher levels of formal education and training are more likely to establish cooperation agreements for their firms. This argument is summarized in the following hypothesis: 
H1: Higher levels of education and training of the entrepreneur stimulates SMEs to establish inter-firm (formal and informal) cooperation agreements.

The entrepreneurial motivation to start a new venture is a topic widely discussed in the organizational literature. The premise for studies on this subject is that the understanding of entrepreneurs' motivations can help determine their behavioral patterns (Robichaud, McGraw, and Roger 2001, p. 189). Some studies consider intrinsic motivations, extrinsic motivations, autonomy and independence, and the security and well-being of the family as different motivational factors to become an entrepreneur (Kuratko, Hornsby, and Naffziger 1997). Other studies contemplate the broad categories of opportunity versus necessity entrepreneurs. While the first category refers to entrepreneurs who start a business in order to pursue an opportunity in the market, the second refers to entrepreneurs motivated by unemployment situations or dissatisfaction with their jobs (Reynolds et al. 2002). In this respect, we postulate that entrepreneurial motivations could influence the entrepreneur's attitudes with respect to inter-firm cooperation, as proposed in the following hypothesis:

H2: The type and intensity of the entrepreneur's motivation influence SMEs to establish inter-firm (formal and informal) cooperation agreements.

A third factor at the individual level that may influence the propensity to cooperate is the entrepreneur's social capital. This refers to the level of trust, reliability and reciprocity in social networks (Cookie, and Wills 1999). Social capital plays an important role in entrepreneurship as it influences knowledge acquisition (Cookie, and Wills 1999) and enables the development of relationships based on trust that contribute to entrepreneurial success (Slotte-Kock, and Coviello 2010). A high level of social capital is characterized by interpersonal and institutional trust. 
On the one hand, interpersonal trust is the result of information obtained from social interactions, leading to the formation of positive expectations regarding the behavior of particular others (Rus, and Iglic 2005, p. 374). Hadjielias and Poutziouris (2015) confirmed interpersonal trust as a critical condition for the emergence and maintainance of cooperative relations between family businesses. Friendship and values congruence is important to stimulate SMEs to cooperate together in the first instance. Therefore we could expect that entrepreneurs with higher levels of interpersonal trust are more inclined to establish informal cooperation agreements as they feel more confident about the reciprocity of potential partners. We sumarize our argument in the following hypothesis:

H3: A high level of interpersonal trust stimulates SMEs to establish informal interfirm cooperation agreements.

"Institutional trust goes beyond specific sets of exchange partners" (Zucker 1986, p. 63) such as family, friends and acquaintances. Thus, "Actors base their expectations regarding the behaviour of others whom they do not know on the quality of the institutional system" (Rus, and Iglic 2005, p.374). Institutions help to generalize trust among actors and allow them to "trust (or not to trust) others who are involved in the same institutions even though they may be strangers" (Rus, and Iglic 2005, p. 375). This kind of trust is considered essential to the functioning of socio-economic systems and as a starting phase of inter-organizational relationships (Bachmann 2001). Entrepreneurs who trust institutions may be more likely to cooperate based on formal agreements, as they believe they have institutional support to mitigate opportunistic actions or to solve problems that may arise in cooperation. We summarize our argument in the following hypothesis:

H4: A high level of institutional trust positively stimulates SMEs to establish formal inter-firm cooperation agreements. 


\subsection{Organizational-level Factors}

In addition to individual-level factors, organizational factors may also explain why SMEs establish cooperative agreements. The propensity to take risks (Lumpkin, and Dess 1996), the firm's innovation activity (Martínez-Román, and Romero 2016), and the insertion in global value chains (Gereffi, Humphrey, and Sturgeon 2005) may influence cooperation.

The entrepreneurial orientation of firms includes key dimensions such as "the propensity to act autonomously, the willingness to innovate and take risks, and a tendency to be aggressive toward competitors and proactive relative to marketplace opportunities" (Lumpkin, and Dess 1996, p. 137). In this respect, firms that are more willing to take risks may have more chances of attaining better results and grow. Firms more oriented toward the development of their businesses may be more willing to cooperate in order to access resources and enhance organizational performance. Moreover, those firms with a predisposition to taking risks might be also inclined to cooperate and eventually assume the costs derived from a possible failure in the cooperation activity. Therefore, we propose the following hypothesis:

H5: A high level of risk taking propensity stimulates SMEs to establish (formal and informal) inter-firm cooperative agreements.

The second organizational factor we analyze refers to investment in innovation. The literature shows that firms develop inter-firm agreements to become more innovative and enhance the outcomes of R\&D investments (Powell, Koput, and Smith-Doerr 1996; Baum, Calabrese, and Silverman 2000; Martínez-Román, and Romero 2016). Through cooperation, firms can access knowledge and technologies, share resources and accelerate the innovation 
process. However, collaborative innovation also involves risks regarding intellectual property and profit sharing. Therefore, firms that invest in innovation projects may prefer formal cooperation agreements, rather than informal ones, to protect their interests. Based on these considerations, we propose the following hypothesis:

H6: The development of innovation projects stimulates SMEs to establish formal cooperation agreements.

A firm's insertion in Global Value Chains (GVC) may also impact its willingness to cooperate. SMEs can use horizontal inter-firm cooperation agreements in order to be able to access destination markets abroad for their products or international suppliers for their inputs. Moreover, value chains are increasingly more frequently organize all over the world. GVCs are generally associated with narrow relationships between large multinational corporations and local SMEs operating in different phases of the value chain (Gereffi 1999; Gereffi, Humphrey, and Sturgeon 2005; Humphrey, and Schmitz 2002). The organization of production and coordination of different actors participating in GVCs often imply vertical cooperation relationships between companies. The interaction between buyers and suppliers within the GVCs can be highly complex on some occasions. It often requires the flexibility of trust-based relationships, but also the legal security associated with formal contracts that make the key aspects of the agreements explicit. These are especially relevant for the sides involved. This particularly applies to GVCs characterized by a network-type of governance, such as "relational value chains" (Gereffi, Humphrey, and Sturgeon 2005). In this respect, we propose the following hypothesis:

H7: A high level of insertion in Global Value Chains stimulates SMEs to establish inter-firm cooperation relationships that require a combination of formal and informal agreements. 


\subsection{Institutional-level factors}

Finally, the institutional environment may also influence the adoption of cooperative strategies. Institutions refer to the formal and informal rules of the environment (North 1990) that significantly affect organizations. Studies suggest that factors such as the level of taxes (Bohata, and Mladek 1999; Hashi 2001; Bartlett, and Bukvic 2001) and the regulatory environment (Brunetti et al 1998; Hashi 2001) directly influence firms' outcomes. Environmental barriers such as a lack of financing (Pissarides et al. 2000; Hashi 2001; Bartlett, and Bukvic 2001; Fuentelsaz et al. 2015) and of trained professsionals (Aidis 2005) also affect firms. Cooperation may help SMEs to overcome some institutional barriers. By joining forces and developing collaborative strategies, SMEs can solve some problems that they would be unable to handle individually. Therefore, we expect that entrepreneurs who perceive higher levels of institutional barriers will be more willing to develop inter-firm cooperative agreements to overcome these barriers. This argument is summarized in the following hypothesis:

H8: The entrepreneur's perception of a high level of institutional barriers stimulates SMEs to establish (formal and informal) cooperation agreements.

\section{Data and Methodology}

Data for this study come from a survey of 1,587 SMEs in Spain. The survey was conducted in the last quarter of 2010 in these six regions: Andalusia, Murcia, Extremadura, the Basque Country, Madrid and Navarre. These regions were selected intending to provide a broad picture of the whole national economy. All types of firms up to 250 employees were included in the study with the exception of self-employed people without employees. The 
survey was addressed to the person having the role of entrepreneur. The entrepreneur was defined in this respect as any business owner (or co-owner) who also carries out managerial functions within the firm. The stratified sample - with quotas for size groups and sectors was representative of the business population of every region included in the study with an error of about six percent at a confidence level of 95.5 percent. A response rate of 20.8 percent was obtained in the fieldwork. No bias was detected between respondents and nonrespondents. The questionnaire used in this research included queries about inter-firm cooperation agreements and three levels of explanatory variables: the entrepreneur's individual characteristics, the organization characteristics and the entrepreneur's perception of the institutional environment.

\subsection{Measures}

Dependent variable: Inter-firm cooperation agreements. This multinomial variable reflects the existence of collaboration agreements between firms. It takes value 0 in the case of absence of any type of cooperation with other firms, 1 if exclusively informal cooperation is observed, 2 if only formal cooperation agreements exist and 3 in the case of the existence of both informal and formal cooperation agreements.

Independent Variables: Entrepreneur's Individual Characteristics.

- Education (edu): this variable takes the value 1 for the managers/business owners without any studies, 2 for those with primary education, 3 for those with secondary education, 4 for those with higher professional training and 5 for those with a university degree.

- Business education (bus_edu): this variable takes the value 1 for those entrepreneurs who had attended any course about entrepreneurship, management, business administration or specific topics related to their business activity and 0 in the negative case. 
- Intrinsic entrepreneurial motivation (int_mot): The entrepreneurs interviewed were asked about their level of agreement with the following statement: "I became an entrepreneur because this was the best option for my personal and professional development". The answers were coded using a 7-pointscale.

- Extrinsic motivation (ext_mot): The entrepreneurs interviewed were asked about their level of agreement with the following statement: "Because this way I earn more money than working as an employee.” The answers were coded using a 7-pointscale.

- Continuity motivation (cont_mot): The entrepreneurs interviewed were asked about their level of agreement with the following statement: "Because I had to continue with a family business". The answers were coded using a 7-pointscale.

- Interpersonal trust (pers_trust): The questionnaire included three queries about the level of trust in three diferente groups: Family, friends and acquaintances. The answers were coded using a 7-pointscale. We carried out a principal component analysis from these three variables and the first factor obtained is our final measurement for personal trust.

- Institutional trust (inst_trust): The questionnaire also included three variables related to the entrepreneur's level of trust in diferent types of organizations: financial institutions, clients and suppliers, and public institutions. As in the previous case, the answers were coded using a 7-pointscale and the first factor obtained from the principal component analysis was used as a measurement for institutional trust.

\section{Independent Variables: Organizational Characteristics}

- Risk taking propensity (risk): The entrepreneurs were asked about their level of agreement with the following statement: "In general, a tendency to undertake highly-risky projects exists in my business". The answers were coded using a 7-pointscale. 
- Investment in innovation (innov): This is a binary variable that takes value 1 for those companies that had made some expenditure in innovation activities in the previous three years and 0 in the negative case.

- Sales to foreign clients (export): This variable indicates the percentage of the total sales that corresponds to exports. Answers were coded using six intervals - up to 10 percent, between 10 and 25 percent, between 25 and 50 percent, between 50 and 75 percent, between 75 and 100 percent or 100 percent - treated as an ordinal variable.

- Purchases from foreign suppliers (import): This variable indicates the percentage of the total purchases that corresponds to imports. Answers were coded in the same way as the previous variable.

Independent Variables: Entrepreneur's Perceptions of the Institutional Environment. The entrepreneurs were asked to assess their perception of the relevance of the following obstacles for their business activity (using a 7-pointscale): Tax burden (tax), Difficulty in finding qualified workers (qual_work), Administrative and legal obstacles (adm_leg), Difficulty in getting funding (funding) and Poor infrastructures (infrast).

Control variables. In addition, some control variables were included in the econometric models to isolate the effect of our explanatory variables. The entrepreneur's gender was included to capture possible gender bias. The firm size, measured by the number of employees, was included in the analysis as a continuous variable. Smaller companies should have stronger incentives to cooperate as a strategy to overcome the limitations associated with their limited size. Firm age was measured as the number of years of activity since the creation of the firm and was included to control for the effect of the different stages across the firm's life cycle. Three sectorial dummies were also considered for the manufacturing industry, construction and services. 
In order to identify the determinants of formal and informal inter-firm cooperation, we use the Multinomial Logit Model (MLN) in this paper. We assume that the firms consider four cooperation strategies simultaneously, non-cooperation included. Since the data consist of individual-specific characteristics, we estimated the model

$$
\ln \left[\frac{\operatorname{Prob}\left(Y_{i}=j \mid \mathbf{x}_{i}\right)}{\operatorname{Prob}\left(Y_{i}=0 \mid \mathbf{x}_{i}\right)}\right]=\mathbf{x}_{i}^{\prime} \boldsymbol{\beta}_{j}, \quad j=1,2,3
$$

where $j=0$, absence of any type of cooperation with other firms, is the base outcome. $\mathbf{x}_{i}$ is the vector of independent variables for the i-th individual.

MLNs are based on the assumption that odds ratios are independent of the other alternatives. Therefore adding or deleting alternatives does not affect the odds among the remaining alternatives. In our frame, the odds ratio of any two cooperation strategies are independent of the probabilities of the other cooperation strategies. This property is called the Independence from Irrelevant Alternatives (IIA). The IIA assumption could not be very plausible if firms viewed two strategies as similar rather than independent. In this case, the model passed the test of the independence of irrelevant alternatives (IIA). We used the Hausman-McFadden test and the Small-Hsiao test for the validity of this assumption.

Table 1 provides the descriptive statistics of the independent variables. Of the 1,587 firms, 55.82 percent do not have inter-firm cooperation agreements. However, 44.18 percent of the firms cooperate with other firms, informal cooperation being almost as frequent $(18.15$ percent) as formal cooperation (17.40 percent). Only 8.6 percent of SMEs in our survey cooperate formally and informally at the same time.

\section{[ Insert Table 1 about here ]}

The average entrepreneur in the survey is a male (71.7 percent) with high levels of formal education and training (47.35 percent have a university degree and 72 percent have attended a business course), mainly driven by an intrinsic motivation and, in general, they perceive high levels of institutional barriers, except for poor infrastructures. The average SME 
in the sample has eight employees, is twenty years old, operates mainly in the services sector (47.5 percent), made some expenditure in innovation activities (66 percent) and did not carry out import and export activities. The correlation matrix is presented in Appendix A. Correlations are generally low to moderate, indicating that there is a low risk of facing collinearity issues.

\section{Results}

The results of the estimation of the MLM are shown in Table 2.

\section{[ Insert Table 2 about here ]}

The results confirm H1 regarding the positive influence of entrepreneur's education on the establishment of informal cooperation agreements, formal agreements and mixed agreements. Specific business-related courses also positively influence the establishment of informal and formal agreements. These results confirm previous studies and show that the entrepreneur's education may not only make him/her more aware of the benefits of cooperation (Kim, and Novorta 2014), but can also provide tools for managing both formal and informal inter-firm agreements and minimize the possible risks of such strategies.

$\mathrm{H} 2$ is partially confirmed by the results. Entrepreneurs with intrinsic motivation might found new firms based on business opportunities and have more growth ambition (Guzmán, and Santos 2001). Therefore, we could expect them to be more aware of business needs to succeed and develop cooperation agreements to address these resources needs. Nevertheless, the analysis only identified the influence of intrinsic motivation in the establishment of mixed interfirm agreements. Besides that, extrinsic motivation seems to have a negative influence on formal cooperation agreements. Those entrepreneurs motivated by higher incomes could, according to these results, be more individualistic and less cooperative. Furthermore, those business owners running family business and motivated by continuity are less likely to 
develop formal and informal cooperation agreements together. One explanation for this result is that these entrepreneurs are less oriented to business opportunities (Kuratko, Hornsby, and Naffziger 1997) and therefore less open to cooperating to develop their firms. Overall, intrinsic motivation seems to be the entrepreneurial motivation that leads to more cooperative SMEs.

H3 was also confirmed by the results. There is a positive relationship between the level of interpersonal trust and the creation of informal inter-firm cooperation agreements. This result supports previous studies on the role of interpersonal trust for the establishment of cooperative agreements in small firms (Hadjielias, and Poutziouris 2015). Yet our research extends this understanding by showing that interpersonal trust specifically promotes informal cooperation. Therefore, a positive relationship between this variable and the establishment of formal inter-firm agreements and mixed agreements was not found. Our findings reinforce the relationship hypothesized by sociologists (Woolthuis, Hillebrand, and Nooteboom 2005) that trust can successfully substitute contracts.

Likewise, $\mathrm{H} 4$ predicted a positive influence of institutional trust on formal inter-firm agreements. The underlying logic of this hypothesis is that entrepreneurs who trust institutions feel legally supported to establish agreements and solve conflicts that may arise (Rus, and Iglic 2005). Nonetheless, our results do not support the relation between institutional trust and any kind of cooperation agreement. One possible explanation is that trust in institutions is not enough to promote cooperation in the context of SMEs. Entrepreneurs may consider that, even in countries with strong institutions, the cost of settling disputes would be high for their firms, making cooperation disadvantageous.

Our second set of hypotheses proposes that organizational-level variables influence the establishment of cooperation agreements. The results totally support H5 regarding the positive influence of risk taking propensity on formal, informal and mixed inter-firm cooperative 
agreements. Such a result makes sense since inter-firm cooperation involves interdependencies and risks. Despite the potential benefits of collaboration, partners may behave opportunistically and the results intended may not be achieved. Thus, those entrepreneurs inclined to taking risks may be more willing to cooperate to enhance their results, despite the risks these strategies can present.

The second variable at the organizational level that we analyze refers to the firm's innovation activity. As proposed in H6, there is a positive relationship between investment in innovation projects and formal cooperation agreements. On the one hand, SMEs seeking to innovate are more likely to cooperate to achieve successful results (Zeng, Xie, and Tam 2010). Cooperation may provide access to knowledge, and physical and technological resources that enhance innovation (Powell, Koput, and Smith-Doerr 1996; Baum, Calabrese, and Silverman 2000). On the other hand, these firms establish formal agreements in order to minimize the risks of knowledge and intellectual property misappropriation by their partners.

The last variable at the organizational level refers to the firm's integration into Global Value Chains. The results confirm $\mathrm{H} 7$ that a higher level of insertion in GVCs positively influences SMEs to establish mixed inter-firm cooperation agreements, both in the case of foreign sales and acquisitions from foreign suppliers. The participation in GVCs usually involves agreements with one or more large companies, requiring some kind of formal agreement providing guarantees for both the small and the large companies involved (Gereffi, Humphrey, and Sturgeon 2005; Humphrey, and Schmitz 2002). Notwithstanding, the involvement of SMEs in GVCs also requires their flexibility to meet buyers' requests and maintain high standards of services. In this respect, informal collaboration is also convenient as an ingredient in the relationships between SMEs, their industrial clients and other possible local partners that can help them to meet the requests from large corporations. 
The hypothesis testing the relationship between institutional barriers and cooperation agreements (H8) showed contradictory results. Data analysis confirmed that entrepreneurs who perceive greater difficulties finding skilled workers established more formal cooperation agreements. It was also found that the perception of administrative and regulatory obstacles positively influences informal cooperation agreements and the difficulty of financing explains the formation of mixed cooperation agreements. In all these three situations, the formation of inter-firm agreements can help firms to overcome difficulties imposed by the institutional environment. However, the results also indicated a negative influence of taxes and fees on the establishment of informal agreements and formal agreements. Such a negative influence contradicts previous studies that found only positive relations between institutional barriers and cooperation (Li, Zheng, and Wang 2016).

Finally, the control variables showed that SMEs in the service sector are the ones that have a higher probability of developing a combination of informal and formal cooperation with other firms. Furthermore, larger SMEs tend to establish more formal and mixed interfirm cooperation agreements. Besides that, the results showed that female entrepreneurs made less informal and formal interfirm agreements than their male counterparts. The literature linking gender and cooperation is contradictory. Antony and Horn (2003, p 293) reported a "widespread sense that women and men are different: in particular, that women are more cooperative". The experiment of Seguino, Steven and Lutz (1996) showed that men have more individualistic behaviors, while women are more cooperative. Explanations for this difference in behavior are diverse. Some authors argue that the different structural positions that women and men ocupy in society (Fischer, and Oliker 1983; Antony, and Horn 2003) and evolutionary pressures (Lueptow, and Garovich-Szabo 2001) stimulate different kinds of behaviors. As a consequence, women have internalized more pro-social values (Beutel, and Marini 1995) that make them more cooperative than men. 
On the other hand, some studies based on experiments in artificial settings reported that women are less cooperative. For instance, Brown-Kruse and Hummel (1993, p. 264) suggest that such a difference is "the result of how young boys and girls play. Boys are more likely to play team games, resulting in a more highly developed sense of cooperation and an increased ability to resolve disputes". According to this school of thought men cooperate better than women because they have more practice at it. Irwin, Edwards and Tamburello (2015) have another explanation. They argue that women experience more risk aversion. "In situations with a high degree of fear incentive and low trust, women may view the situation as risky and thus choose not to cooperate" (Irwin, Edwards, and Tamburello 2015, p. 329). Our study contributes to this stream of research by showing that women are probably less cooperative in business settings due to their higher risk aversion.

\section{Conclusion and Implications}

Why and how do SMEs cooperate? These are the two key questions that this paper has aimed to answer. Thus, we have explored the determinants of inter-firm cooperation in SMEs from different perspectives that consider the individual, organizational and institutional factors involved in the decision to cooperate using formal or informal agreements. Our article differentiates between those SMEs which do not cooperate, those that exclusively maintain informal agreements, those which exclusively have formal agreements and those that develop both types of cooperation agreements. By adopting this typology, we have been able to particularly study the behavior of those SMEs that develop a complex cooperation activity that implies formal and informal content at the same time. This article shows that this is an interesting group of SMEs which opt for these reinforced cooperative relationships with other firms due to specific factors. This delimitation, together with the integrating and multilevel 
approach proposed, allows this article to contribute to the previous literature on cooperation in SMEs.

According to our results, from an individual perspective, an entrepreneur's education and interpersonal trust favors inter-firm informal cooperation in SMEs. Furthermore, from an organizational perspective, the higher risk taking propensity positively influences informal cooperation. Finally, from an institutional perspective, the perception of high tax burdens destimulates informal cooperation in SMEs. In the case of formal cooperation, some of these determinants -the entrepreneur's education, risk taking and the perception of tax burdensremain as relevant factors, whereas personal trust is not a significant determinant for this type of agreements. Yet from an individual perspective, extrinsic motivation is observed to have a negative influence on formal cooperation. From the organizational perspective, innovation activities lead SMEs to establish formal cooperation agreements with other companies and, from an institutional perspective, the problems in finding qualified workers positively influence formal cooperation as well.

Likewise, it is interesting to observe the particular factors that encourage SMEs to develop cooperation relationships that require a mix of formal and informal elements. From an individual perspective, the entrepreneur's education is a positive factor and entrepreneurial motivations are shown to also have a relevant influence. In this respect, an intrinsic motivation of the entrepreneur is more frequent in the SMEs which combine formal and informal cooperation, whereas an entrepreneur's continuity motivation decreases the probability of this type of reinforced cooperation. From an organizational perspective, in addition to the positive influence of the risk taking propensity, the type of insertion in value chains is an especially important aspect in this case. Hence, those SMEs that participate more intensively in GVCs - exporting their output or/and importing their inputs - have a higher probability of being involved in cooperation relationships that combine formal and informal 
cooperation. Finally, from an institutional perspective, this type of cooperation is more frequent in the case of firms which perceive difficulties in their access to funding.

As a first theoretical implication, our paper shows that different factors explain the formation of formal and informal SMEs inter-firm agreements. It represents a first effort to jointly analyze variables at the individual, organizational and institutional level that explain the formation of inter-firm cooperative agreements. A second implication has to do with the behavior of the female entrepreneurs in our sample. Previous studies were mostly based on experiments (Brown-Kruse, and Hummel 1993; Seguino, Steven, and Lutz, 1996) and showed contradictory results, while our study reports that women are less cooperative than men in real business settings.

From a management perspective, cooperation with other agents within the value chain, emerges as a key issue for firm competitiveness and success due to the increasing significance of GVCs. The management of these cooperation relationships implies risks and challenges and frequently requires a combination of formalized and informal agreements. The efficient design and control of these cooperative frameworks represents an emergent challenge for strategic management.

These results have also implications from a policy perspective. According to our analysis, SMEs use cooperation relationships to facilitate innovation strategies and/or the participation in GVCs, among other initiatives. Catalyzing inter-firm cooperation could be therefore a useful line of intervention in the fields of industrial, enterprise and regional policy. Likewise, entrepreneurial education programs and training activities that increase the skills and competences of the entrepreneurs and managers can indirectly favor cooperation in SMEs. Finally, our results suggest that taxes and administrative fees can discourage cooperation agreements in SMEs. This is also an issue to be taken into account by policymakers. 
Further research could study the determinants of cooperation in SMEs, differentiating not only the levels of formalization of the relationships, but also the material content of the cooperation (in production, purchases, $\mathrm{R} \& \mathrm{D}$, marketing, etc.). In addition, it would be interesting to study whether the level of formalization of cooperation agreements has consequences in terms of the results of these initiatives.

\section{References}

Aidis, R. (2005). 'Institutional Barriers to Small-and Medium-sized Enterprise Operations in Transition Countries,' Small Business Economics, 25 (4), 305-317.

Aldrich, H., and E. R. Auster (1986). 'Even Dwarfs Started Small: Liabilities of Age and Size and Their Strategic Implications,' Research in Organizational Behavior, 8 (1986), 165186.

Anthony, D., and C. Horne. (2003). 'Gender and Cooperation: Explaining Loan Repayment in Micro-credit Groups,' Social Psychology Quarterly, 293-302.

Azadegan, A., K. J. Dooley, P. L. Carter, and J. R. Carter. (2008). 'Supplier Innovativeness and the Role of Interorganizational Learning in Enhancing Manufacturer Capabilities,' Journal of Supply Chain Management, 44 (4), 14-35.

Bachmann, R. (2001). 'Trust, Power and Control in Trans-organizational Relations,' Organization Studies, 22 (2), 337-365.

Bartlett, Will, and V. Bukvič. (2001) 'Barriers to SME Growth in Slovenia,' MOST: Economic Policy in Transitional Economies, 11 (2), 177-195

Baum, J. A., T. Calabrese, and B. S. Silverman. (2000). 'Don't go it Alone: Alliance Network Composition and Startups' Performance in Canadian Biotechnology,' Strategic Management Journal, 21(3), 267-294.

Bohata, Marie, and J. Mladek. (1999). 'The Development of The Czech SME Sector,' Journal of Business Venturing, 14 (5), 461-473.

Brown-Kruse, J., and D. Hummels. (1993). 'Gender Effects in Laboratory Public Goods Contribution: Do Individuals Put Their Money Where Their Mouth is?,' Journal of Economic Behavior \& Organization, 22 (3), 255-267.

Brunetti, A., G. Kisunko, and B. Weder. (1998). 'Credibility of Rules and Economic Growth: Evidence From a Worldwide Survey of The Private Sector,' The World Bank Economic Review, 12 (3), 353-384.

Cooke, P., and D. Wills. (1999). 'Small Firms, Social Capital and the Enhancement of Business Performance Through Innovation Programmes,' Small Business Economics, 13 (3), 219-234.

Deligonul, S., U. Elg., E. Cavusgil, and P. N. Ghauri. (2013). 'Developing Strategic Supplier Networks: An Institutional Perspective,' Journal of Business Research, 66 (4), 506-515.

Delmar, F. and P. Davidsson. (2000): 'Where do They Come From? Prevalence and Characteristics of Nascent Entrepreneurs,' Entrepreneurship \& Regional Development, $12(1), 1-23$. 
Dyer, J. H., and H. Singh. (1998) 'The Relational View: Cooperative Strategy and Sources of Interorganizational Competitive Advantage.' Academy of Management Review, 23 (4), 660-679.

Fischer, C. S., and S. J. Oliker. (1983). 'Research Note on Friendship, Gender, and The Tife Cycle,' Social Forbes, 62, 124-132.

Fuentelsaz, L., C. González, J. P. Maícas, and J. Montero. (2015). 'How Different Formal Institutions Affect Opportunity and Necessity Entrepreneurship,' BRQ Business Research Quarterly, 18 (4), 246-258.

Gereffi, G. (1999). 'International Trade and Industrial Upgrading in The Apparel Commodity Chain,' Journal of International Economics, 48 (1), 37-70.

Gereffi, G., J. Humphrey, and T. Sturgeon. (2005). 'The Governance of Global Value Chains,' Review of International Political Economy, 12 (1), 78-104.

Gronum, S., M. L. Verreynne, and T. Kastelle. (2012). 'The Role of Networks in Small and Medium-sized Enterprise Innovation and Firm Performance,' Journal of Small Business Management, 50 (2), 257-282.

Gulati, R., and M. Gargiulo. (1999). 'Where Do Interorganizational Networks Come From?,' American Journal of Sociology, 104, 177-231.

Guzmán, J. and F. J. Santos. (2001): 'The Booster Function and the Entrepreneurial Quality: an Application to the Province of Seville,' Entrepreneurship \& Regional Development, $13(3), 211-228$.

Hadjielias, E., and P. Poutziouris. (2015). 'On the Conditions for the Cooperative Relations Between Family Businesses: The Role of Trust,' International Journal of Entrepreneurial Behavior \& Research, 21 (6), 867-897.

Hashi, I. (2001) 'Financial and Institutional Barriers to SME Growth in Albania: Results of an Enterprise Survey,' MOST: Economic Policy in Transitional Economies, 11 (3), 221-238.

Havnes, P. A., and K. Senneseth. (2001). 'A Panel Study of Firm Growth Among SMEs in Networks,' Small Business Economics, 16 (4), 293-302.

Humphrey, J., and H. Schmitz. (2002). 'How does Insertion in Global Value Chains Affect Upgrading Industrial Clusters?,' Regional Studies, 36 (9), 1017-1027.

Irwin, K., K. Edwards., and J. A. Tamburello. (2015). 'Gender, Trust and Cooperation in Environmental Social Dilemmas,' Social Science Research, 50, 328-342.

Kangasharju, A., and S. Pekkala. (2002). 'The Role of Education in Self-employment Success in Finland,' Growth and Change 33 (2), 216-237.

Kim, Y., and N. S. Vonortas. (2014). 'Cooperation in The Formative Years: Evidence From Small Enterprises in Europe,' European Management Journal, 32 (5), 795-805.

Kuratko, D. F., J. S. Hornsby, and D. W. Naffziger. (1997). 'An Examination of Owner's Goals in Sustaining Entrepreneurship,' Journal of Small Business Management, 35 (1), 24.

Li, X., Zheng, Y., and C. L. Wang. (2016). 'Inter-firm Collaboration in New Product Development in Chinese Pharmaceutical Companies,' Asia Pacific Journal of Management, 33 (1), 165-193.

Liñán, F., J. C. Rodríguez-Cohard, J. M. Rueda-Cantuche. (2011). 'Factors Affecting Entrepreneurial Intention Levels: A Role For Education,' International Entrepreneurship and Management Journal ,7 (2), 195-218. 
Lueptow, L. B., L. Garovich-Szabo, and M. B. Lueptow. (2001). 'Social Change and The Persistence of Sex typing: 1974-1997,' Social Forces, 80 (1), 1-36.

Lumpkin, G. T., and G. G. Dess. (1996). 'Clarifying the Entrepreneurial Orientation Construct and Linking it to Performance,' Academy of Management Review, 21 (1), 135172.

Martínez-Román, J.A. and I. Romero. (2016). 'Determinants of Innovativeness in SMEs: Disentangling Core Inovation and Technology Adoption Capabilities,' Review of Managerial Science, DOI 10.1007/s11846-016-0196-x.

Narula, R. (2004). 'R\&D Collaboration by SMEs: New Opportunities and Limitations in The Face of Globalisation,' Technovation, 24 (2), 153-161.

North, D. C. (1990). 'Institutions, Institutional Change and Economic Performance,' Cambridge University Press.

O'Donnell, A. (2014). 'The Contribution of Networking to Small Firm Marketing,' Journal of Small Business Management, 52 (1), 164-187.

Okamuro, H. (2007). 'Determinants of Successful R\&D Cooperation in Japanese Small Businesses: the Impact of Organizational and Contractual Characteristics,' Research Policy, 36 (10), 1529-1544.

Osborn, R. N., and J. Hagedoorn. (1997). 'The Institutionalization and Evolutionary Dynamics of Interorganizational Alliances and Networks,' Academy of Management Journal, 40 (2), 261-278.

Oxley, J. E. (1999). 'Institutional Environment and the Mechanisms of Governance: the Impact of Intellectual Property Protection on the Structure of Inter-firm Alliances,' Journal of Economic Behavior \& Organization, 38 (3), 283-309.

Pfeffer, J., and G. R. Salancik. (2003). 'The External Control of Organizations: A Resource Dependence Perspective. Stanford University Press,'.

Pissarides, F., M. Singer, and J. Svejnar. (2000). 'Objectives and Constraints of Entrepreneurs: Evidence From Small and Medium-sized Enterprises in Russia and Bulgaria,' European Bank for Reconstruction and Development London.

Powell, W. W., K. W. Koput, and L. Smith-Doerr. (1996). 'Interorganizational Collaboration and the Locus of Innovation: Networks of Learning in Biotechnology,' Administrative Science Quarterly, 116-145.

Pyke, F. (1992). 'Industrial Development Through Small-firm Cooperation: Theory and Practice,' International Labour Organization.

Reynolds, P. D., S.M. Camp, W. D. Bygrave, E. Autio, and M. Hay. (2002). 'Global Entrepreneurship Monitor gem 2001 Summary Report,' London Business School and Babson College.

Ring, P. S., and A. H. Van de Ven. (1994). 'Developmental Processes of Cooperative Interorganizational Relationships,' Academy of Management Review, 19 (1), 90-118.

Robichaud, Yves, E. McGraw, and R. Alain. (2001). 'Toward The Development of a Measuring Instrument for Entrepreneurial Motivation,' Journal of Developmental Entrepreneurship, 6 (2), 189.

Robinson, P.B., and E. A. Sexton. (1994). 'The Effect of Education and Experience on Selfemployment Success,' Journal of Business Venturing, 9 (2), 141-156. 
Rus, A., and H. Iglič. (2005). 'Trust, Governance and Performance the Role of Institutional and Interpersonal Trust in SME Development,' International Sociology, 20 (3), 371-391.

Schoonjans, B., P. Van Cauwenberge, and H. Vander Bauwhede. (2013). 'Formal Business Networking and SME Growth,' Small Business Economics, 41 (1), 169-181.

Seguino, S., T. Stevens, and M. Lutz. (1996). 'Gender and Cooperative Behavior: Economic Man Rides Alone,' Feminist Economics, 2 (1), 1-21.

Sigmund, S., T. Semrau, and D. Wegner. (2015). 'Networking Ability and The Financial Performance of New Ventures: Moderating Effects of Venture Size, Institutional Environment, and Their Interaction,' Journal of Small Business Management, 53 (1), 266-283.

Smith, K. G., S. J. Carroll, and S. J. Ashford. (1995). 'Intra-and Interorganizational Cooperation: Toward a Research Agenda,' Academy of Management Journal, 38 (1), 7 23.

Williamson, O. E. (1975) 'Markets and Hierarchies,' New York, Pahrke (1993), 26-30.

Woolthuis, R., B. Hillebrand, and B. Nooteboom. (2005). 'Trust, Contract and Relationship Development,' Organization Studies, 26 (6), 813-840.

Zaheer, A., R. Gulati, and N. Nohria. (2000). 'Strategic Networks,' Strategic Management Journal, 21 (3), 203.

Zeng, S. X., X. M. Xie, and C. M. Tam. (2010). 'Relationship Between Cooperation Networks and Innovation Performance of SMEs,' Technovation, 30 (3), 181-194.

Zucker, L.G. (1986) 'Production of Trust: Institutional Sources of Economic Structure, 18401920. Research in Organizational Behavior, 8, 53-111. 

Table 1. Descriptive statistics of variables used in regression

\begin{tabular}{lcccc}
\hline Variable & Mean & Std. Dev. & Min & Max \\
\hline Education & 3.966 & 1.149 & 1 & 5 \\
Business education & 0.716 & 0.451 & 0 & 1 \\
Intrinsic motivation & 5.498 & 2.063 & 1 & 7 \\
Extrinsic motivation & 4.006 & 2.381 & 1 & 7 \\
Continuity motivation & 2.724 & 2.577 & 1 & 7 \\
Interpersonal trust & 0.004 & 1.000 & -5.619 & 1.627 \\
Institutional trust & 0.001 & 0.999 & -2.249 & 2.814 \\
Risk taking propensity & 3.176 & 1.888 & 1 & 7 \\
Investment in innovation & 0.660 & 0.474 & 0 & 1 \\
Sales to foreign clients & 1.336 & 0.869 & 1 & 6 \\
Purchases foreign suppliers & 1.505 & 1.132 & 1 & 6 \\
Tax burden & 5.200 & 2.106 & 1 & 7 \\
Qualified workers & 3.580 & 2.370 & 1 & 7 \\
Administrative and legal obstacles & 3.948 & 2.350 & 1 & 7 \\
Funding & 4.095 & 2.484 & 1 & 7 \\
Poor infrastructures & 2.512 & 1.946 & 1 & 7 \\
Female & 0.292 & 0.455 & 0 & 1 \\
Firm size & 7.795 & 14.678 & 1 & 250 \\
Firm age & 20.482 & 13.648 & 4 & 138 \\
Manufacturing & 0.108 & 0.310 & 0 & 1 \\
Construction & 0.156 & 0.363 & 0 & 1 \\
Services & 0.475 & 0.500 & 0 & 1 \\
\hline
\end{tabular}


Table 2. Regression results (base category = "no cooperation")

\begin{tabular}{|c|c|c|c|c|c|c|}
\hline & \multicolumn{2}{|c|}{$\begin{array}{c}\text { Informal } \\
\text { agreements }\end{array}$} & \multicolumn{2}{|c|}{$\begin{array}{c}\text { Formal } \\
\text { agreements }\end{array}$} & \multicolumn{2}{|c|}{$\begin{array}{c}\text { Informal + Formal } \\
\text { agreements }\end{array}$} \\
\hline & $\beta$ & S.E. & $\beta$ & S.E & $\beta$ & S.E. \\
\hline \multicolumn{7}{|l|}{ Individual-level factors } \\
\hline \multicolumn{7}{|l|}{ Education } \\
\hline Education & $0.158^{* *}$ & 0.066 & $0.228^{* * *}$ & 0.069 & $0.297^{* * *}$ & 0.099 \\
\hline Business education & $0.340^{* *}$ & 0.168 & $0.693^{* * *}$ & 0.185 & 0.004 & 0.230 \\
\hline \multicolumn{7}{|l|}{ Entrepreneurial motivations } \\
\hline Intrinsic motivation & -0.005 & 0.036 & 0.055 & 0.039 & $0.102^{*}$ & 0.060 \\
\hline Extrinsic motivation & -0.040 & 0.032 & $-0.090^{* * *}$ & 0.032 & -0.006 & 0.045 \\
\hline Continuity motivation & -0.015 & 0.030 & -0.046 & 0.032 & $-0.159^{* * *}$ & 0.051 \\
\hline \multicolumn{7}{|l|}{ Social capital } \\
\hline Interpersonal trust & $0.239^{* * *}$ & 0.077 & 0.105 & 0.076 & 0.082 & 0.102 \\
\hline Institutional trust & -0.018 & 0.075 & 0.018 & 0.076 & 0.11 & 0.101 \\
\hline \multicolumn{7}{|l|}{ Organizational-level factors } \\
\hline Risk taking propensity & $0.076^{*}$ & 0.039 & $0.092^{* *}$ & 0.039 & $0.102^{*}$ & 0.053 \\
\hline Investment in innovation & 0.234 & 0.156 & $0.418^{* *}$ & 0.165 & 0.245 & 0.223 \\
\hline Sales to foreign clients & 0.020 & 0.091 & 0.13 & 0.086 & $0.284^{* * *}$ & 0.093 \\
\hline Purchases foreign suppliers & 0.039 & 0.066 & -0.022 & 0.068 & $0.16^{* *}$ & 0.078 \\
\hline \multicolumn{7}{|l|}{ Institutional-level factors } \\
\hline Tax burden & $-0.112^{* * *}$ & 0.036 & $-0.067^{*}$ & 0.037 & -0.044 & 0.052 \\
\hline Qualified workers & 0.038 & 0.032 & $0.097^{* * * *}$ & 0.032 & 0.041 & 0.044 \\
\hline Administrative and legal obstacles & $0.065^{*}$ & 0.034 & -0.016 & 0.035 & -0.037 & 0.047 \\
\hline Funding & 0.009 & 0.032 & 0.019 & 0.033 & $0.159^{* * *}$ & 0.046 \\
\hline Poor infrastructures & 0.017 & 0.038 & 0.018 & 0.039 & 0.027 & 0.052 \\
\hline \multicolumn{7}{|l|}{ Control Variables } \\
\hline Female & $-0.705^{* * *}$ & 0.176 & $-0.290^{*}$ & 0.165 & -0.106 & 0.224 \\
\hline Firm size & 0.005 & 0.006 & $0.010^{*}$ & 0.006 & $0.022^{* * *}$ & 0.006 \\
\hline Firm age & -0.001 & 0.006 & 0.004 & 0.006 & 0.008 & 0.008 \\
\hline Manufacturing & 0.261 & 0.261 & -0.305 & 0.285 & 0.533 & 0.369 \\
\hline Construction & 0.311 & 0.237 & 0.152 & 0.236 & 0.421 & 0.361 \\
\hline Services & 0.302 & 0.19 & -0.025 & 0.186 & $0.547^{* *}$ & 0.278 \\
\hline Constant & $-2.227^{* * *}$ & 0.463 & $-3.271^{* * *}$ & 0.497 & $-5.714^{* * *}$ & 0.726 \\
\hline \multicolumn{7}{|l|}{ Log likelihood $=-1660.8109$} \\
\hline LR $\operatorname{chi} 2(66)=246.79^{* * * *}$ & & & & & & \\
\hline
\end{tabular}

Note: Number Observations $=1,553$. S.E. $=$ Standard Error.

* Significant at the $90 \%$ level. **Significant at the $95 \%$ level. ***Significant at the $99 \%$ level. 


\section{Appendix A: Correlation Matrix of independent variables}

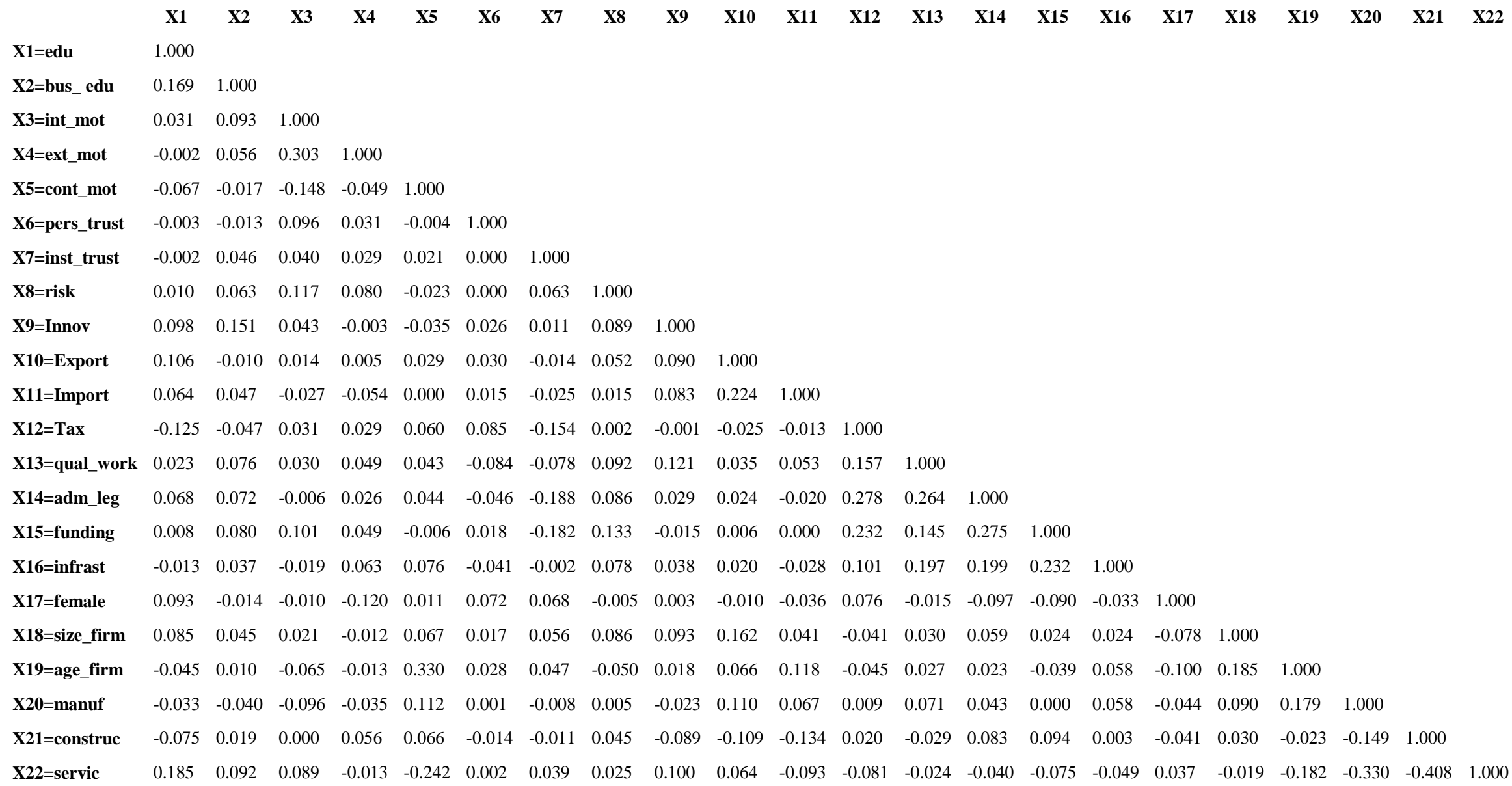

